\title{
Article \\ Structure and Mechanical Properties of the 18 Ni300 Maraging Steel Produced by Spark Plasma Sintering
}

\author{
Angelina Strakosova *, Filip Průša (D), Alena Michalcová (D) and Dalibor Vojtěch \\ Department of Metals and Corrosion Engineering, University of Chemistry and Technology, Prague, Technická 5, \\ 16628 Prague 6, Czech Republic; Filip.Prusa@vscht.cz (F.P.); Alena.Michalcova@vscht.cz (A.M.); \\ Dalibor.Vojtech@vscht.cz (D.V.) \\ * Correspondence: Angelina1.Strakosova@vscht.cz
}

Citation: Strakosova, A.; Průša, F.; Michalcová, A.; Vojtěch, D. Structure and Mechanical Properties of the 18Ni300 Maraging Steel Produced by Spark Plasma Sintering. Metals 2021, 11, 748. https://doi.org/10.3390/ met11050748

Academic Editor:

Cătălin-Daniel Constantinescu

Received: 23 March 2021

Accepted: 29 April 2021

Published: 1 May 2021

Publisher's Note: MDPI stays neutral with regard to jurisdictional claims in published maps and institutional affiliations.

Copyright: (c) 2021 by the authors. Licensee MDPI, Basel, Switzerland. This article is an open access article distributed under the terms and conditions of the Creative Commons Attribution (CC BY) license (https:// creativecommons.org/licenses/by/ $4.0 /)$.

\begin{abstract}
In this work, a new approach for compaction of the gas-atomized $18 \mathrm{Ni} 300$ maraging steel at two different temperatures of $1050^{\circ} \mathrm{C}$ and $1150^{\circ} \mathrm{C}$ using a progressive SPS technology is studied. Moreover, the influence of two heat treatments combining solution annealing and aging (SAT) and simply aging treatment (AT) on the microstructure and mechanical properties is investigated. It is found that samples compacted at $1050{ }^{\circ} \mathrm{C}$ had higher porosity compared to the almost non-porous material produced at $1150{ }^{\circ} \mathrm{C}$. In addition, the difference of $100{ }^{\circ} \mathrm{C}$ for the compaction temperature successfully reduces the porosity from $0.86 \%$ down to $0.08 \%$. Additionally, we discovered that the higher the compaction temperature, the higher the amount of retained $\gamma$-Fe which positively affects the ductility of the samples. The subsequential heat treatment results in precipitation strengthening via the $\mathrm{Ni}_{3}$ Mo precipitates. Microhardness of the SPS1050 and SPS1150 samples increase from $303 \pm 13$ HV0.1 and $360 \pm 5$ HV0.1 to $563 \pm 31$ HV0.1 and $606 \pm 17$ HV0.1, respectively. The sample compacted at $1150{ }^{\circ} \mathrm{C}$ shows the highest ultimate tensile strengths reaching up to $1940 \pm 6 \mathrm{MPa}$, while also showing $4 \%$ ductility.
\end{abstract}

Keywords: maraging steel $18 \mathrm{Ni} 300$; spark plasma sintering; heat treatment; mechanical properties; microstructure

\section{Introduction}

Maraging steels are ultra-high-strength martensitic steels with a very low carbon content (generally $\leq 0.03 \mathrm{wt} . \%$ ). At the same time, these steel types are highly alloyed with Ni, Co, Mo [1,2] reaching high ultimate strengths and high hardnesses. Further, the steels are ductile, tough, and also are easily weldable $[3,4]$. The main reason for such good mechanical properties of the maraging steels is the precipitation hardening during heat treatment, allowing to form a few types of nano-sized precipitates $\left(\mathrm{Ni}_{3}(\mathrm{Mo}\right.$, $\mathrm{Ti}), \mathrm{Fe}_{2} \mathrm{Mo}$ ) homogeneously dispersed within the material volume [5-7]. Due to their admirable properties, these steels have a wide range of applications, e.g., can be used for tooling components, aerospace and hydrospace industry, as well as for motor racing applications [4,8-10]. Considering the good weldability, maraging steels are suitable for production not only via classical methods but also by way of modern processes, such as additive manufacturing $[4,9,11,12]$ and powder metallurgy $[13,14]$.

Spark plasma sintering (SPS) is one of the progressive powder metallurgy methods which started to develop in 1906 [15]. The first device for commercial use was manufactured in 1965 (Japan) [16]. Between years 2001 and 2004, four types of SPS machines with different systems (multi-heat, tunnel, rotary table, and shuttle) were registered for specific industrial applications by Tokita [17-20]. Nowadays, a wide range of materials including polymers [21], ceramics [22], and different types of metal alloys [14,23-27] are compacted via SPS technology. The method can be briefly described as a rapid heating process with a heating rate of up to hundreds ${ }^{\circ} \mathrm{C} / \mathrm{min}$ due to a controlled flow of current throughout the compacted powder or the die itself. At the same time, external uniaxial pressure is applied 
to the sample and the whole process is typically finished within a few minutes, which suppresses diffusion-related effects in the material including microstructural coarsening, phase transformations, and others [28].

The main advantages of SPS against conventional powder metallurgy methods are (1) higher heating rate; (2) lower sintering temperatures; (3) shorter holding time [15]; (4) almost nonporous structure of the compacts; and (5) suppression of the microstructural changes during SPS method [29,30]. However, the process itself allows the creation of bulk materials with only a simple geometry. That fact can be considered as one of two disadvantages compared to the selective laser melting (SLM) technology. The second one is that materials produced by the SLM method have a very fine cell structure.

There is a lot of studies involved in describing the maraging steel produced by additive manufacturing [3-5,9-11]. However, up to these days, there are only a few scientific reports that have described the influence of sintering conditions on the properties of maraging steels. In the work [13], Antsiferov et al. have studied maraging steel produced by powder metallurgy method. In the work of others [31-33], the authors have studied how sintering of maraging steel depends on different types of supplements. Only Menapace et al. [14] focused their research on the $18 \mathrm{Ni} 300$ maraging steel produced by the more modern technology of spark plasma sintering.

In this work, the influence of different SPS settings on the microstructure and mechanical properties of high-strength $18 \mathrm{Ni} 300$ maraging steel was studied. Particularly, two different consolidation temperatures of $1050^{\circ} \mathrm{C}$ and $1150{ }^{\circ} \mathrm{C}$ and two different consequential heat treatments were used as variables.

\section{Materials and Methods}

The $18 \mathrm{Ni} 300$ (also denoted as EN 1.2709) maraging steel powder which was used for compaction via SPS technology was purchased from Sichuan Hermus. The powder particle morphology was observed using a scanning electron microscope (TESCAN VEGA 3 LMU, Brno, Czech Republic). The powder particle distribution was measured using Ferret's diameter technique in the ImageJ software. The results of the X-ray fluorescence analysis (XRF, ARL 9400 XP, Thermo ARL, Ecublens, Switzerland) are shown in Table 1. These results are in a good match with the chemical composition given in the ASTM A579/579M-17A prescription as well as the work of others [5,10,34].

Table 1. Chemical composition of the $18 \mathrm{Ni300}$ alloy.

\begin{tabular}{lccccccccc}
\hline Element & Fe & Ni & Co & Mo & Ti & C & Al & Cr & Si, Mn \\
\hline$[$ Wt.\%] & Bal. & 19.3 & 9.2 & 5.1 & 0.7 & $\leq 0.03$ & 0.05 & 0.05 & $\leq 0.1$ \\
\hline
\end{tabular}

The powder material has been compacted using FCT Systeme HP D 10 spark plasma sintering device (SPS, FCT Systeme, HP-D 10, Rauenstein, Germany) using a pressure of $80 \mathrm{MPa}$, a heating rate of $100^{\circ} \mathrm{C} / \mathrm{min}$ until reaching the compaction temperature either of 1050 or $1150^{\circ} \mathrm{C}$ with a dwell time of $10 \mathrm{~min}$. After the compaction, the heating was turned off and the sample was cooled down with the maximal cooling speed of the device. For each compaction, $20 \mathrm{~g}$ of the powder was used, producing rounded samples with $20 \mathrm{~mm}$ in diameter and $8 \mathrm{~mm}$ in height (Figure 1). The sample's surface porosity was determined using the threshold method to color each pore and to calculate their area fraction.

Consequentially, two different heat treatments were applied for both samples. The first consisted of solution annealing $\left(820^{\circ} \mathrm{C}\right.$ for $1 \mathrm{~h}$, air cooling) and aging treatment $\left(490^{\circ} \mathrm{C}\right.$ for $6 \mathrm{~h}$, air-cooling), while the second one was composed of only aging treatment using the same conditions. Thus, these samples investigated in this work will be referred accordingly to chosen conditions of thermal treatment as is shown in Table 2.

The metallographic cross-sections were prepared accordingly to the conditions mentioned in our previous work [5]. Microstructural development as a result of different thermal treatments was documented using the above-mentioned SEM and by a trans- 
mission electron microscope (TEM, JEOL 2200 FS, Akishima, Japan) equipped by energy dispersive spectrometer (EDS, Oxford Instruments, $80 \mathrm{~mm}^{2}$, High Wycombe, UK). The phase composition of the studied material was determined by the X-ray diffraction spectroscopy (XRD, PANalytical X'Pert Pro, Almelo, The Netherlands) using Co-K $\alpha$ source $(\lambda=0.17929 \mathrm{~nm})$. These measurements were done in a $2 \theta$ range of $6-110^{\circ}$ with a step size of $0.039^{\circ}$ and duration of $175.185 \mathrm{~s} / \mathrm{step}$.

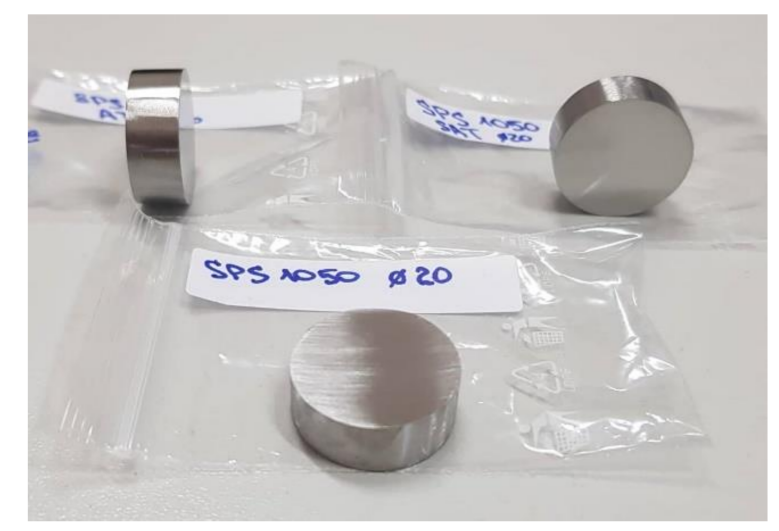

Figure 1. Photo of the experimental samples.

Table 2. Designation of studied samples compacted by SPS at two temperatures of 1050 and $1150{ }^{\circ} \mathrm{C}$, accordingly, to the chosen heat treatment done in an electric resistance furnace.

\begin{tabular}{lcccc}
\hline & \multicolumn{3}{c}{ Condition of Chosen Heat Treatment } & Sample Designation \\
\cline { 2 - 5 } Heat treatment mode & $\begin{array}{c}\text { Solution annealing: } \\
820^{\circ} \mathrm{C} / 1 \mathrm{~h} \text {, air cooling }\end{array}$ & Aging: $490^{\circ} \mathrm{C} / 6 \mathrm{~h}$, air cooling & SPS 1050 SAT & SPS 1150 SAT \\
\cline { 2 - 5 } & - & Aging: $490^{\circ} \mathrm{C} / 6 \mathrm{~h}$, air cooling & SPS 1050 AT & SPS 1150 AT \\
\hline
\end{tabular}

The Vickers microhardness of the material was measured using a FUTURE TECH FM-700 (FUTURE-TECH CORP., Kawasaki-City, Japan) with a load of $100 \mathrm{~g}$ and a dwell time of $10 \mathrm{~s}$. To provide sufficient data sets, ten measurements were made on each sample. The tensile properties of the prepared compacts were determined using miniaturized dog bone-like specimens (see Figure 2) used for micro-tensile testing (MTT). For the testing, three specimens were cut in the perpendicular direction to the compaction force used during SPS.
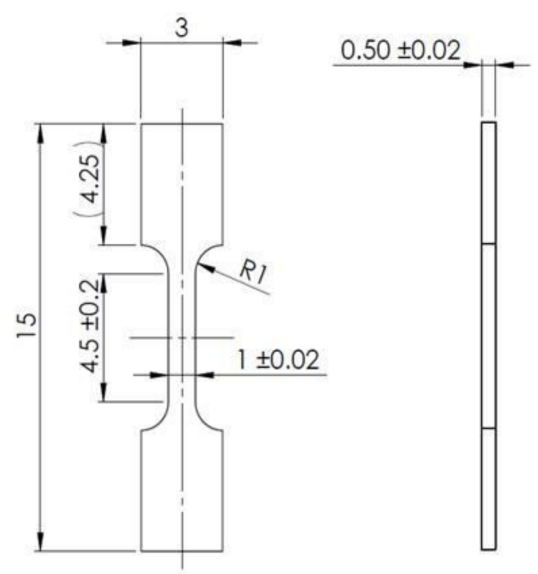

Figure 2. Parameters of the dog bone-like specimens used for tensile testing (all dimensions are in $\mathrm{mm})$. 


\section{Results and Discussion}

\subsection{Characterization of the 18 Ni300 Maraging Steel Powder}

In this work, a novel approach for the compaction of the gas-atomized $18 \mathrm{Ni300}$ maraging steel has been investigated for the first time. The SPS compaction method was used as an alternative to producing bulk semi-samples, which mechanical properties may outperform those prepared by additive manufacturing.

Figure 3a shows the morphology of the $18 \mathrm{Ni} 300$ powder particles. It is observed that most particles had a spherical shape and various diameters. Considering its theoretical application, the shape and size of the powder are very important factors for powder metallurgy technology, e.g., for additive manufacturing, etc. Spherical powder particles with different sizes are beneficial due to their tendency to fill different voids formed between the larger particles. As a result, compressed and sintered samples have lower porosity and thus better mechanical properties. The results of the powder size distribution shown in Figure $3 \mathrm{~b}$ confirmed that the largest fraction of the powder particles have had diameters around $20 \mu \mathrm{m}$. Furthermore, they were accompanied by particles with diameters around $15 \mu \mathrm{m}$ and also in the range of $25-30 \mu \mathrm{m}$, whose fractions corresponded up to $9.9 \%$ and $33.4 \%$, respectively. Further, a rather smaller percentage of significantly smaller particles was also observed, which is beneficial due to their ability to fill any voids formed between larger particles. Considering these results, the particle size distribution within the used powder met the requirements to prepare nearly fully dense compacts via SPS compaction.

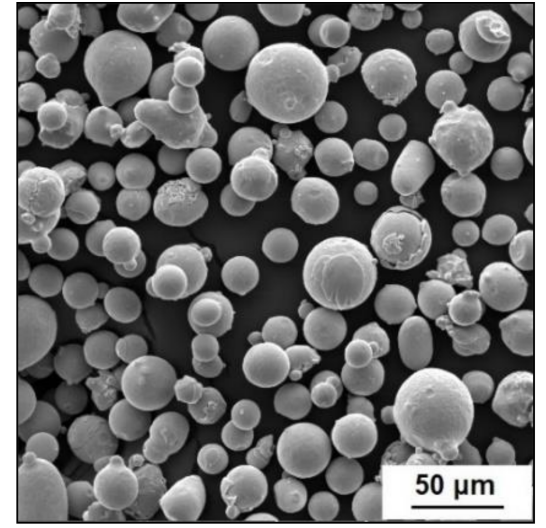

(a)

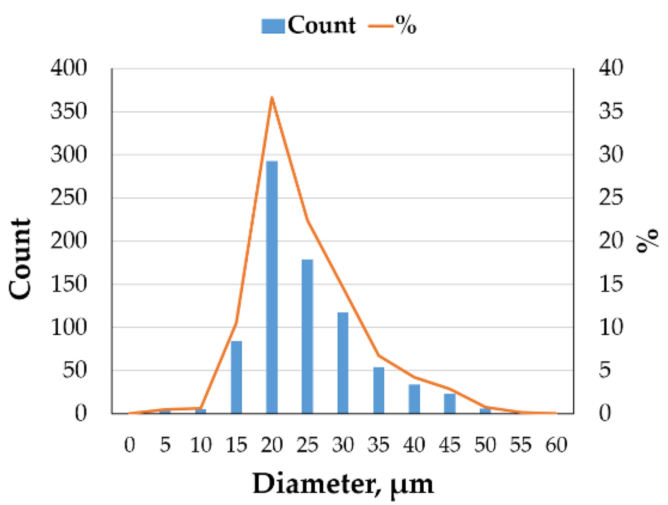

(b)

Figure 3. Properties of the 18Ni300 18-9-5 maraging steel powder showing: (a) particles morphology; (b) size distribution.

The SEM micrograph of a powder particle is shown in Figure 4a, while the phase composition determined by the XRD analysis is shown in Figure $4 \mathrm{~b}$.

The microstructure of the powder consists of various cells which are typical structural components of metal powders produced by gas atomization. It is caused due to the high cooling rate during powder production. Present phases were identified as martensite $(\alpha$-phase) and as retained austenite ( $\gamma$-phase). The presence of a small amount of residual austenite has been also reported in the work of others $[5,8]$ and is related to the preparation technique chosen for the powder production. This is because, during the rapid cooling, the residual austenite does not undergo the phase transformation into martensite. 


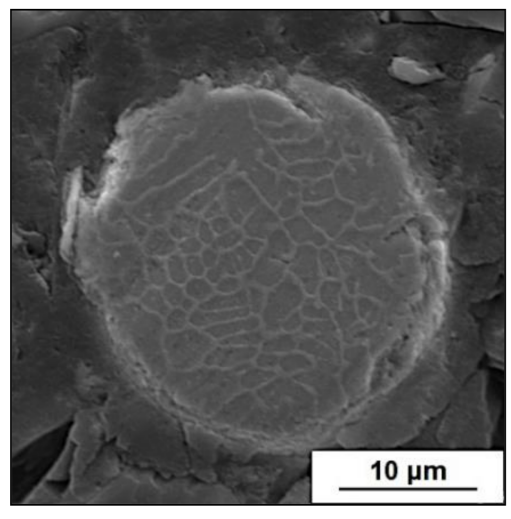

(a)

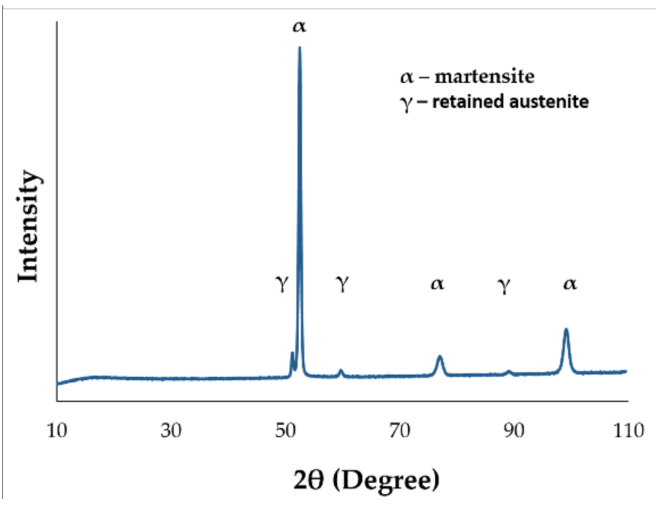

(b)

Figure 4. SEM image of $18 \mathrm{Ni} 300$ maraging steel powder particle cross-section (a) and its X-ray diffraction pattern $(\mathbf{b})$.

\subsection{Microstructure Characterization of the Consolidated 18Ni300 Maraging Steel}

Figure 5 shows the microstructures of investigated material as a result of different temperatures used during the compaction via SPS. It was found that the porosity of the compacts decreased from $0.86 \%$ down to $0.08 \%$ as the SPS compaction temperature changed from 1050 to $1150{ }^{\circ} \mathrm{C}$.

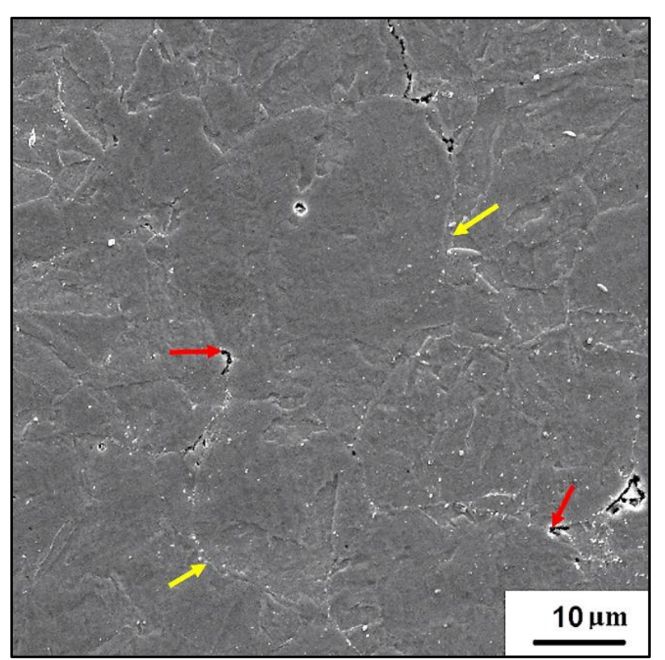

(a)

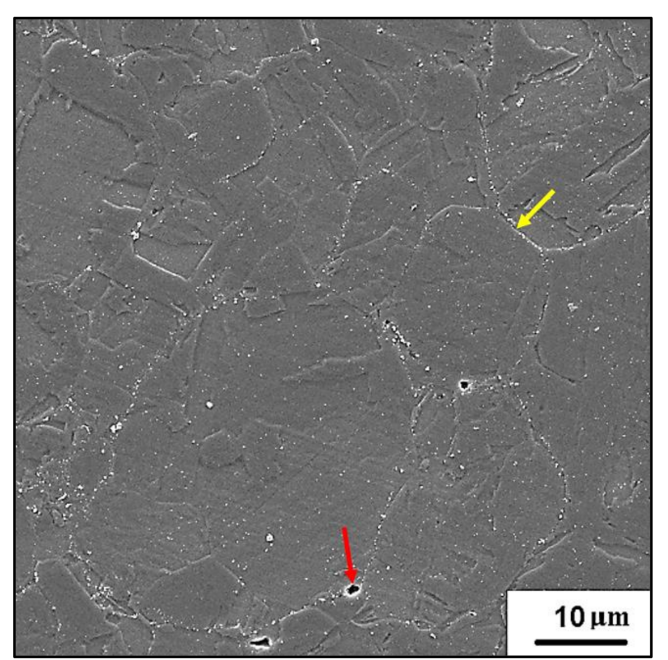

(b)

Figure 5. SEM images of the $18 \mathrm{Ni300}$ maraging steel compacted via SPS at: (a) $1050{ }^{\circ} \mathrm{C}$; (b) $1150{ }^{\circ} \mathrm{C}$.

The microstructure of the sample compacted at lower temperature showed the presence of visible pores that are marked with red arrows in Figure 5a. Among that, deformed powder boundaries (marked with yellow arrows) between each powder particle can be also clearly distinguishable. This means that a temperature of $1050^{\circ} \mathrm{C}$ was partially sufficient to allow increased plastic deformation of the material due to activation of dislocation movements. However, the temperature was not high enough to provide a fully dense material due to the limited welding of present voids within the material. It is observed that the initially observed cellular structure (Figure 4) has changed into an almost fully martensite structure as was confirmed by the XRD analysis (shown below).

Figure $5 \mathrm{~b}$ shows the microstructure of the sample consolidated at $1150{ }^{\circ} \mathrm{C}$ that is similar to the previous one (Figure 5a) except a few differences. Both of the compact samples were composed of coarse martensite laths, but the sample compacted at $1150{ }^{\circ} \mathrm{C}$ showed almost 
zero porosity. This suggests that the compaction temperature was enough to allow easier bonding of each particle, their mutual deformation, and decrease of the porosity.

\subsection{Microstructure after Heat Treatment}

The SEM micrographs of the studied compacts, which underwent two heat treatment modes, combining solution annealing with aging treatment (SAT) or only simply aging treatment (AT), are shown in Figure 6. Similar to the as-compacted samples whose microstructures are shown in Figure 5, any of the chosen heat treatments did not affect the presence of pores, which are marked by red arrows. On the other hand, the SAT treatment application caused a transformation of coarse martensite grains into a fine needle-like microstructure, which is marked by green arrows (Figure 6). It can be seen (Figure 6a,c) that the martensite laths are much finer after SAT treatment compared to an almost unchanged microstructure after AT treatment (Figure $6 \mathrm{~b}, \mathrm{~d}$ ). This phenomenon can be described by the fact that the material was initially heated to a temperature of $820^{\circ} \mathrm{C}$, allowing it to form austenite $[5,34]$. This was followed by air cooling to form martensite. This cooling was slightly faster than compared to the cooling speed typically achieved by the SPS device. Then it was followed by aging at $490^{\circ} \mathrm{C}$, allowing precipitation of nanosized intermetallic phases responsible for precipitation hardening of the maraging steel. Obviously, the combination of an SPS compaction followed by a two-step heat treatment yielded better results, showing a much more refined microstructure containing finer needle-like martensite laths.

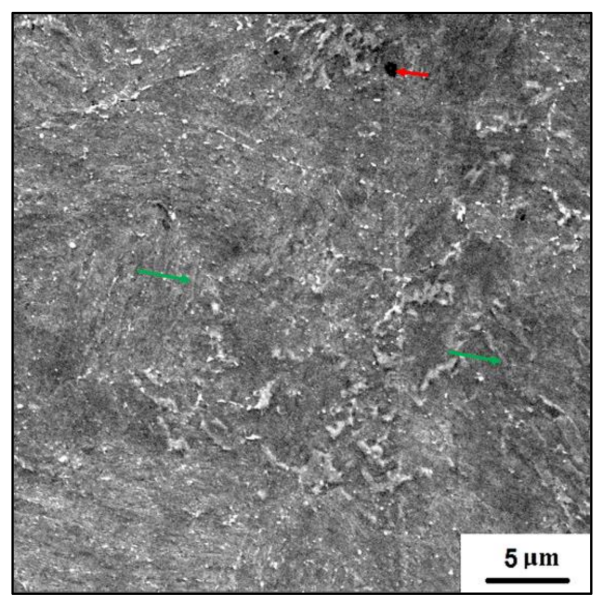

(a)

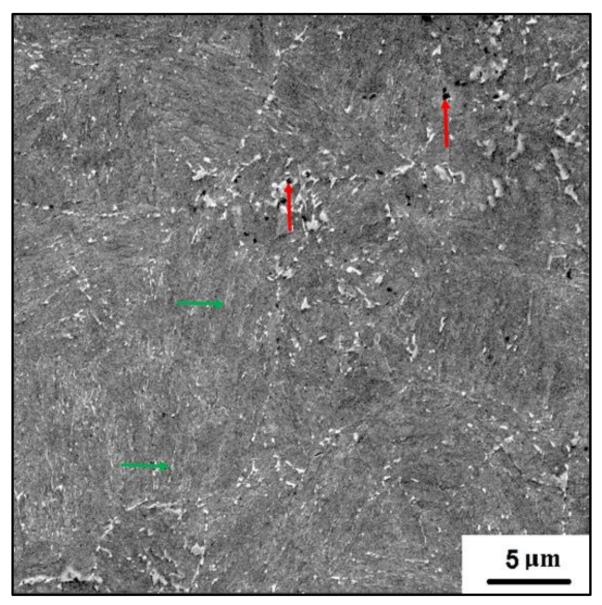

(c)

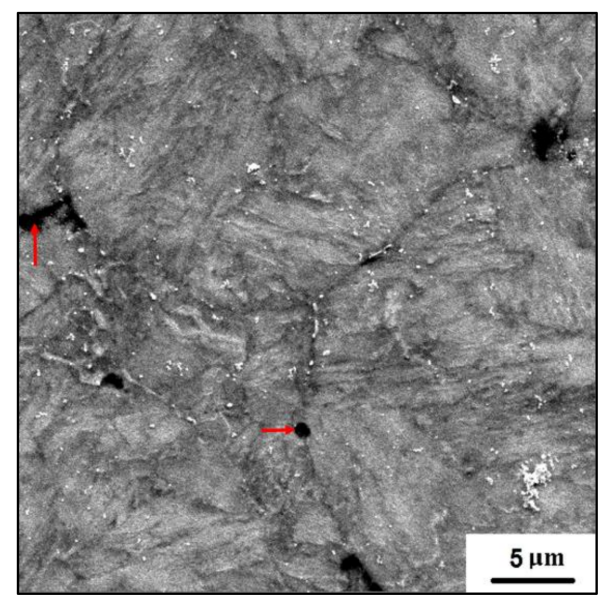

(b)

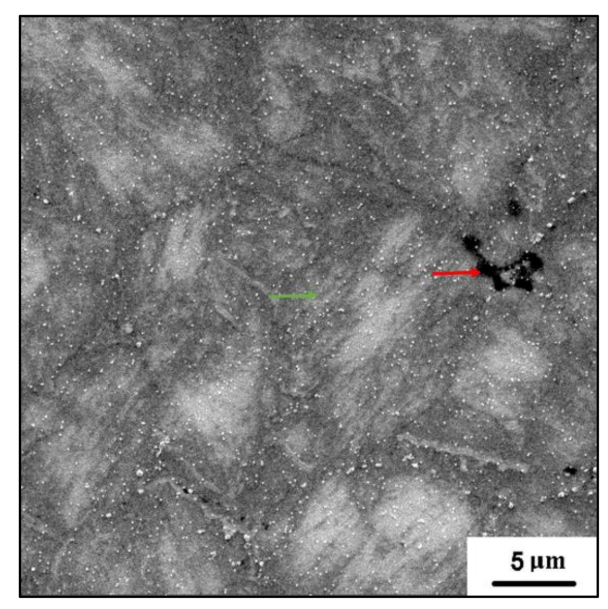

(d)

Figure 6. SEM images of the investigated steel compacted via SPS as a result of the combination of temperature and heat treatment: (a) $1050^{\circ} \mathrm{C} \mathrm{SAT}$; (b) $1050{ }^{\circ} \mathrm{C} \mathrm{AT}$; (c) $1150{ }^{\circ} \mathrm{C} \mathrm{SAT}$; (d) $1150{ }^{\circ} \mathrm{C}$ AT. 
Compared to our previous work [5], which focused on the identical steel produced by SLM technology, the SAT heat treatment mode had the opposite effect on the microstructure development. In the case of the 3D-printed material, the microstructure after the SAT treatment transformed into coarser martensitic laths, while the same heat treatment is done in the case of SPS samples' microstructures being significantly refined. However, the AT treatment did not affect the microstructure of the SPS samples, showing identical behavior as was already reported in the case of the 3D-printed materials [5].

\subsection{Phase Composition of the Maraging Steel}

The phase composition of the $18 \mathrm{Ni3} 300$ maraging steel as a result of the SPS compaction temperature and subsequent heat treatment were studied as is shown in Figure 7. One can see that only one sample (SPS 1050 SAT) was showing only three peaks identified as $\alpha$-phase (martensite). On the other hand, the rest of the materials showed the presence of additional peaks, confirming the presence of the dominating $\alpha$-phase (martensite) and small peaks of the $\gamma$-phase (retained austenite).

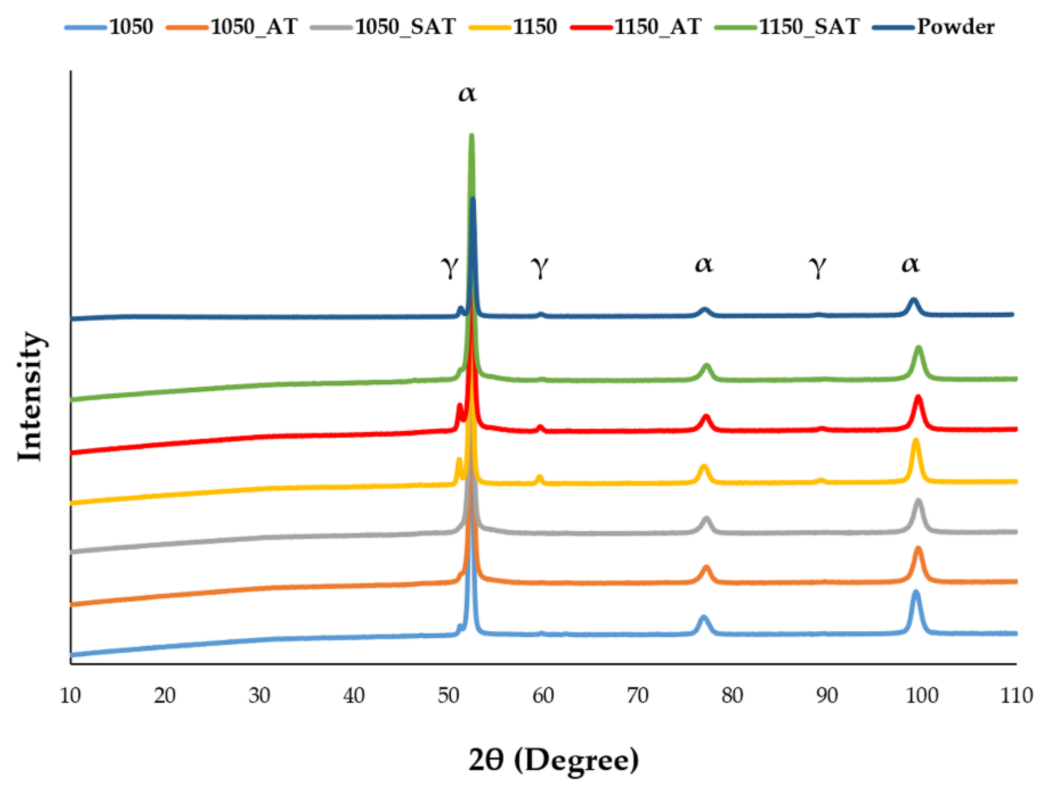

Figure 7. X-ray diffraction patterns of the $18 \mathrm{Ni} 300$ maraging steel.

The percentage content of the phases is summarized in Table 3. As for the temperature of the SPS process, the amount of retained austenite in samples produced at $1150{ }^{\circ} \mathrm{C}$ is higher than in the samples produced at $1050{ }^{\circ} \mathrm{C}$. As it has been already shown, higher compaction temperature, among the different phase compositions, also significantly reduced the residual porosity. Additionally, the full width at half maximum (FWHM) values confirmed the coarsening of the major $\alpha$-Fe phase when compacted at both SPS temperatures. On the other hand, the $\gamma$-Fe of the $1150{ }^{\circ} \mathrm{C}$ sample showed an increase in the volume content as compaction temperature increased. The consequential heat treatment resulted in microstructural refinement of the $\alpha-\mathrm{Fe}$, which was confirmed by the FWHM values.

The consequential heat treatment resulted in microstructural refinement of the $\alpha-\mathrm{Fe}$, which was confirmed by the FWHM values.

It can be seen from Table 3 that the SAT mode allows forming almost $100 \%$ martensite in both the SPS 1050 SAT and SPS 1150 SAT samples. From this point of view, the cooling speed of the SPS itself is responsible for differences within the phases' compositions and foremostly their volume fractions, thus the consequential SAT heat treatment is necessary to increase the amount of martensite while reducing the content of retained austenite. The $\gamma$-phase amount is higher after the AT mode than in the case of combined solution annealing and aging treatment (SAT), which corresponds to the work of Tan et al. [34]. 
After the AT treatment, a 100\% $\alpha$-phase material cannot be achieved because of the inevitable transformation of martensite into a more stable inverted $\gamma$-phase. These results are consistent with the results described in [5], where $100 \% \alpha$-phase was formed only when the SAT regime was applied.

Table 3. Phase composition (vol.\%) of the $18 \mathrm{Ni} 300$ maraging steel under different conditions with the FWHM values for the most intensive peaks from the $\alpha$-Fe phase.

\begin{tabular}{cccc}
\hline Sample & $\boldsymbol{\alpha}$-Fe, $\%$ & FWHM $\left[{ }^{\circ} \mathbf{2}\right.$ Th. $]$ & $\gamma$-Fe, $\%$ \\
\hline Powder & 88 & 0.554 & 12 \\
SPS 1050 & 95 & 0.384 & 5 \\
SPS 1050 SAT & 100 & 0.515 & 0 \\
SPS 1050 AT & 97 & 0.515 & 3 \\
SPS 1150 & 82 & 0.307 & 18 \\
SPS 1150 SAT & 95 & 0.562 & 5 \\
SPS 1150 AT & 84 & 0.563 & 16 \\
\hline
\end{tabular}

\subsection{Mechanical Properties}

The mechanical properties of the materials were investigated to describe the microhardness, ultimate tensile strength (UTS), and elongation of $18 \mathrm{Ni300}$ steel. Figure 8 shows the effect of the heat treatment regime on the microhardness of various samples either produced via SPS or after consequential heat treatment. The samples compacted at $1150{ }^{\circ} \mathrm{C}$ were showing higher hardness and lower standard deviation values to that of samples compacted at $1050{ }^{\circ} \mathrm{C}$. Such a result was achieved due to a significantly lower residual porosity of the first of the aforementioned samples. Additionally, both the heat treatments (including SAT and AT) increased the HV0.1, reaching almost comparable values regardless of the chosen treatment mode, which was caused by the formation of precipitates within the material matrix (see the following paragraph).

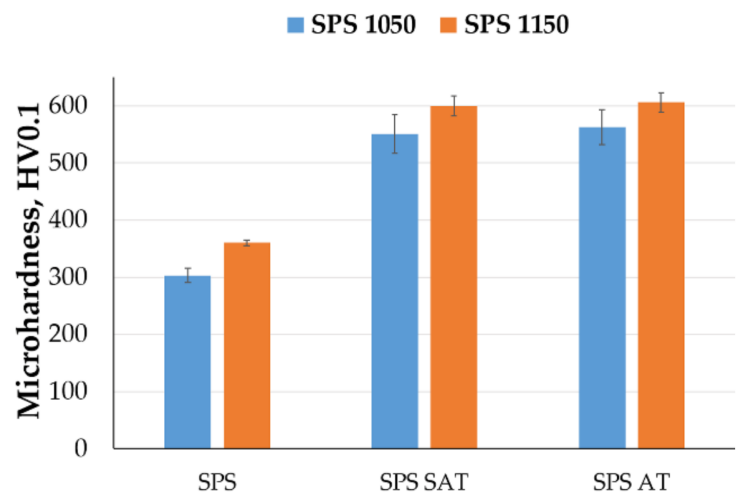

Figure 8. Microhardness of the $18 \mathrm{Ni} 300$ maraging steel as a result of different heat treatment modes.

The influence of the compaction temperature and consequential heat treatment on the tensile strength properties is shown in Figure 9. It is clearly visible that both the temperature of the SPS process and the heat treatment mode have a huge effect on the material properties. In terms of consolidation temperatures, the samples compacted at $1150{ }^{\circ} \mathrm{C}$ showed slightly higher tensile strength values compared to samples compacted at $1050{ }^{\circ} \mathrm{C}$. Additionally, the SPS 1150 samples had much higher elongation values in each state than the SPS 1050 samples. This can be explained by the fact that the higher consolidation temperature contributed to the production of a denser material with better interparticle cohesion. Besides, the higher the compaction temperature, the higher the content of retained $\gamma$-Fe was observed. This behavior can be explained by the initial appearance of the gas-atomized powders with a cellular structure composed of $\alpha$-Fe pools 
surrounded by the $\gamma$-Fe (see Figure 4a). As was discovered in our previous work [5], the $\gamma$-Fe was enriched foremostly by Ni and Mo. Such a morphology and difference in chemical composition were responsible for the formation of two types of $\gamma-\mathrm{Fe}$, one arising from the $\alpha$-Fe having a lower content of the alloying elements while the second one was enriched especially by Ni. Since the diffusivity of elements increases with the temperature, the higher the SPS compaction temperature, the more intensive the distribution of the $\mathrm{Ni}$ within the material stabilizing the larger volume of retained $\gamma$-Fe after the sample is cooled down. Moreover, the higher content of residual austenite and lower amount of deleterious porosity as well as the grain coarsening also contributed to the higher elongation of the SPS 1150 sample. Additional heat treatment resulted in a tremendous increase in the mechanical properties due to the precipitation hardening and partial reduction of the $\gamma$-Fe content. Compared to the results from our previous work [5], while maintaining almost identical UTS values, the ductility of samples compacted at $1150{ }^{\circ} \mathrm{C}$ was higher, compared to the additively manufactured materials with identical chemical composition. This difference was caused by a higher amount of retained $\gamma$-Fe.

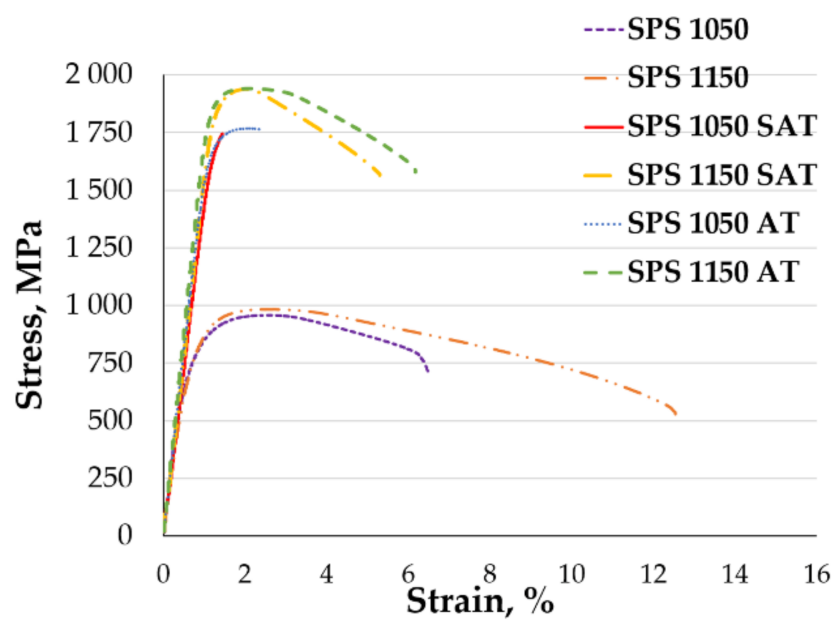

Figure 9. Tensile tests of the $18 \mathrm{Ni} 300$ maraging steel as a result of different heat treatment modes.

It is obvious (Figure 10a) that the UTS values follow the same trend already seen in the case of microhardness development (see Figure 8). However, the effect of the same conditions on the elongation of the studied material was different (Figure 10b). It was observed that the steel had the highest values of elongation in the SPS state, which reflects the presence of low-carbon soft $\alpha$-martensite phase (compare Table 3 and Figure 10b). After heat treatment, the values decreased from $\sim 12 \%$ to $\sim 4 \%$ and from $\sim 6 \%$ to $\sim 1 \%$ in the SPS 1150 and SPS 1050 samples, respectively. The ductility decrease can be associated with the aging procedure during which precipitates are formed within the material, causing precipitation strengthening. Present precipitates effectively hinder the dislocation movement throughout the material that is associated with the ductility decrease.

The results of the mechanical testing of the $18 \mathrm{Ni} 300$ maraging steel produced by SPS technology showed that the temperature of process $1150^{\circ} \mathrm{C}$ is more suitable for producing the steel than $1050{ }^{\circ} \mathrm{C}$. The mechanical properties of the SPS 1150 samples are slightly lower compared to the properties of the same steel produced by wrought metallurgy [35]. However, microhardness and UTS of the consolidated materials are comparable to the maraging steel produced by selective laser melting [5]. 


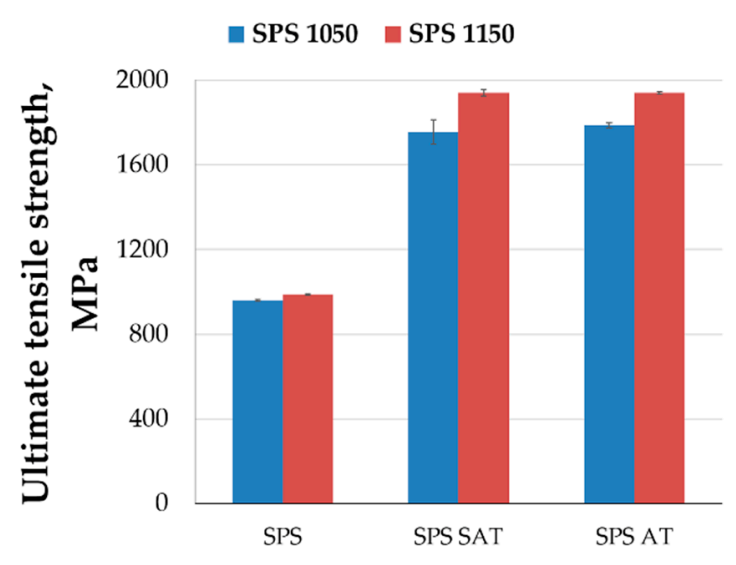

(a)

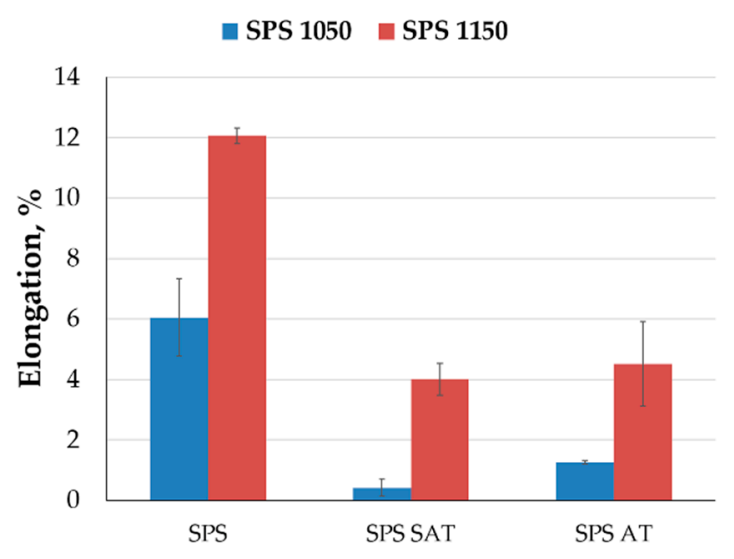

(b)

Figure 10. Summary of the tensile tests of the test materials in their initial state (after SPS) and after heat treatments (SAT and AT) showing: (a) ultimate tensile strengths; (b) elongations.

\subsection{TEM-Analysis}

Based on the microstructure and mechanical property changes of the $18 \mathrm{Ni} 300$ maraging steel, which depends on the SPS process temperature and heat treatment mode, two samples were selected for TEM-analysis: SPS 1150 and SPS 1150 SAT.

Figure 11a,c show detailed TEM micrographs of both consolidated (SPS 1150) and heat-treated (SPS 1150 SAT) samples. It can be seen that in the case of the SPS 1150 sample, lattice defects, which are usually dislocation clusters, are present in the structure (marked by red arrows). In the case of the SPS 1150 SAT sample, a part of a grain boundary is shown by a green arrow. By comparing the TEM images, in both states of the $18 \mathrm{Ni} 300$ maraging steel produced by the SPS method, precipitates of $\mathrm{Ni}_{3} \mathrm{Mo}$ phase were found (marked by yellow arrows). However, it is observed that in the as-consolidated sample (labeled as SPS 1150), the amount of precipitate is very low. The shape of these precipitates appears to be spherical, but more likely, it is caused by the observation axis. The formation of these precipitates is caused due to slow cooling of the material during the manufacturing process. The presence of $\mathrm{Ni}_{3} \mathrm{Mo}$ precipitates was confirmed by the SAED pattern (Figure 11b), which, in addition to the diffraction spots that point to the matrix in the zonal axis [101], are signs of the occurrence of precipitates in the zonal axis [110]. Tan et al. [34] state that precipitates can also be present in the as-printed material without additional heat treatment, and it is caused by rapid solidification and reheating of the melting tracks during the SLM process. As for the heat-treated material (SPS 1150 SAT), the precipitates exhibit a characteristic rod-like shape and are homogeneously distributed within the material. In the SAED pattern, these precipitates are also considered as elongated diffraction points (Figure 11d), and occurred in the axis [212] of the zone when the matrix was observed in the zonal axis $[\overline{211}]$.

The SPS compaction of the $18 \mathrm{Ni} 300$ maraging steel proved itself as a promising method for obtaining low-porosity semi-products, which, while lacking the final dimensions, may offer another advantage, mainly the increased ductility. Furthermore, the results indicate that the amount of retained $\gamma$-Fe may be successfully managed by the compaction temperature that affects the diffusivity of alloying elements, thus increasing/decreasing the volume fraction of this phase after the compaction and even consequential thermal treatment. 


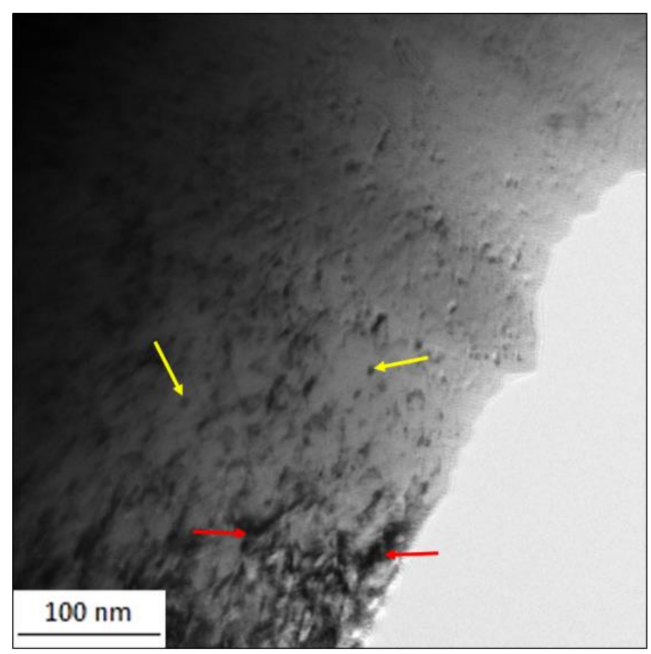

(a)

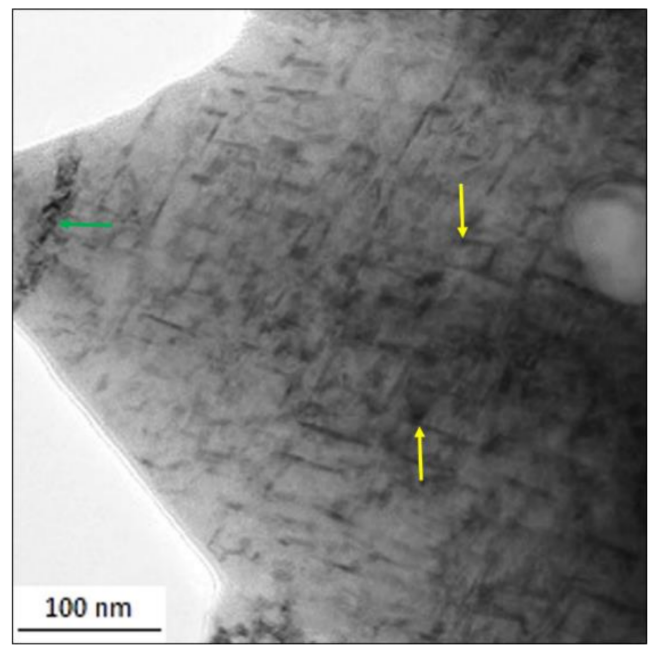

(c)

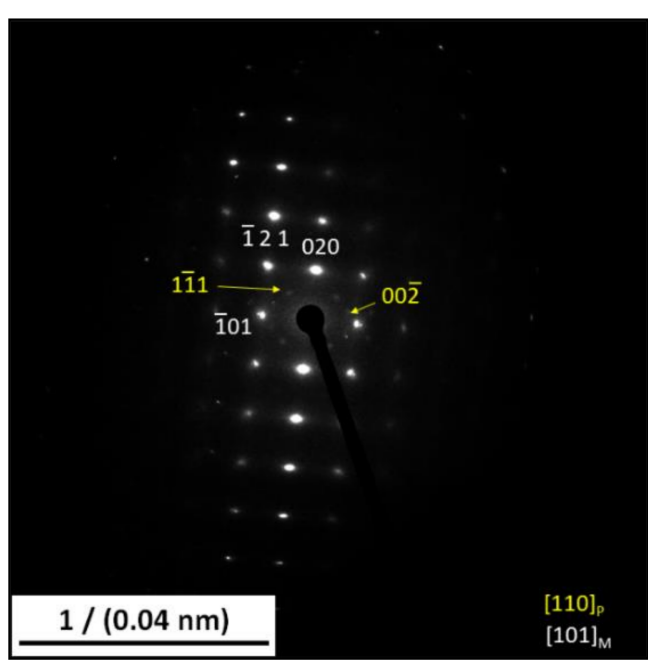

(b)

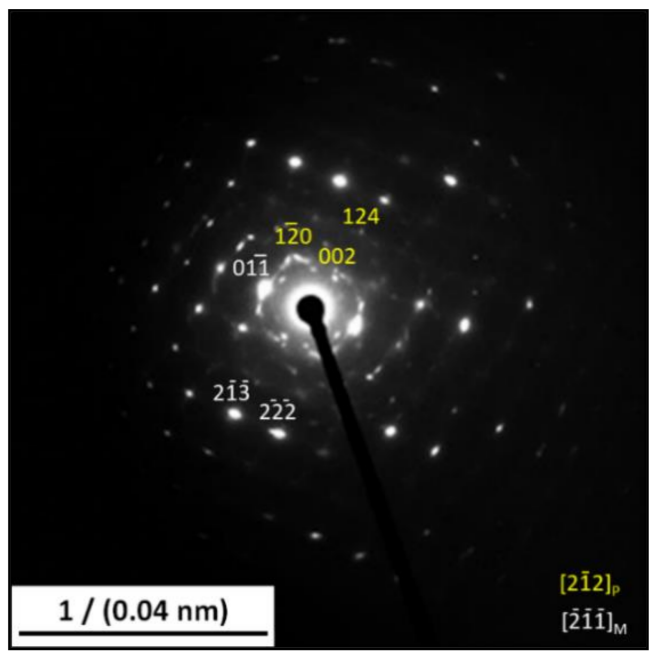

(d)

Figure 11. TEM micrographs: (a) SPS 1150; (c) SPS 1150 SAT; and SAED patterns: (b) SPS 1150; (d) SPS 1150 SAT; of the $18 \mathrm{Ni} 300$ maraging steel.

\section{Conclusions}

The present work demonstrates a novel approach for the compaction strategy for the maraging steels using an SPS to produce almost non-porous material. It was found that the $18 \mathrm{Ni} 300$ maraging steel consolidated at $1150{ }^{\circ} \mathrm{C}$ had a lower value of porosity compared to that produced at $1050{ }^{\circ} \mathrm{C}(0.08 \%$ and $0.86 \%$, respectively). It was proved that the pore content had a favorable effect on mechanical properties in the case of the SPS 1150 material having higher microhardness, UTS, and ductility. Additionally, SAT heat treatment caused microstructural refinement as well as the change in phase proportions (decreasing the $\gamma$-Fe amount from $18 \%$ to $5 \%$ ). Additionally, the formation of nanostructured $\mathrm{Ni}_{3} \mathrm{Mo}$ precipitates resulted in a significant strengthening, reaching a hardness of $606 \pm 17$ HV0.1 and UTS of $1940 \pm 6 \mathrm{MPa}$, respectively. The material showed 4\% ductility, a value larger compared to the same material prepared in our previous work [5]. The UTS of the SPS 1150 samples was slightly lower compared to those which were produced by wrought metallurgy [35] but was comparable to the material produced by selective laser melting [5]. 
Author Contributions: D.V. and A.S. conceived and designed the experiments; A.S., F.P., and A.M. performed the experiments and analyzed the data; A.S. and F.P. wrote this paper. All authors have read and agreed to the published version of the manuscript.

Funding: The research was supported by the grant of Specific university research A1_FCHT_2021_010.

Data Availability Statement: Data is contained within the article.

Acknowledgments: The authors thank the assistance provided by the Research Infrastructure NanoEnviCz, supported by the Ministry of Education, Youth and Sports of the Czech Republic under Project No. LM2018124.

Conflicts of Interest: The authors declare no conflict of interest.

\section{References}

1. Viswanathan, U.K.; Dey, G.K.; Asundi, M.K. Precipitation Hardening in 350 Grade Maraging Steel. Metall. Trans. 1993, 24A, 2429-2442. [CrossRef]

2. Tavares, S.S.M.; da Silva, M.R.; Neto, J.M.; Pardal, J.M.; Cindra Fonseca, M.P.; Abreu, H.F.G.J. Magnetic properties of a Ni-CoMo-Ti maraging 350 steel. Alloy Compd. 2004, 373, 304-311. [CrossRef]

3. Conde, F.F.; Escobar, J.D.; Oliveira, J.P.; Jardini, A.L.; Bose Filho, W.W.; Avila, J.A. Austenite reversion kinetics and stability during tempering of an additively manufactured maraging 300 steel. Addit. Manuf. 2019, 29, 100804. [CrossRef]

4. Jägle, E.A.; Sheng, Z.; Kürnsteiner, P.; Ocylok, S.; Weisheit, A.; Raabe, D. Comparison of Maraging Steel Micro- and Nanostructure Produced Conventionally and by Laser Additive Manufacturing. Materials 2017, 10, 8. [CrossRef]

5. Strakosova, A.; Kubásek, J.; Michalcová, A.; Průša, F.; Vojtěch, D.; Dvorský, D. High Strength X3NiCoMoTi 18-9-5 Maraging Steel Prepared by Selective Laser Melting from Atomized Powder. Materials 2019, 12, 4174. [CrossRef]

6. Moshka, O.; Pinkas, M.; Brosh, E.; Ezersky, V.; Meshi, L. Addressing the issue of precipitates in maraging steels-Unambiguous answer. Mater. Sci. Eng. A 2015, 638, 232-239. [CrossRef]

7. Sha, W.; Cerezo, A.; Smith, G.D.W. Phase Chemistry and Precipitation Reactions in Maraging Steels: Part I. Introduction and Study of Co-containing C-300 Steel. Metall. Trans. A. 1993, 24A, 1221-1232. [CrossRef]

8. Thotakura, G.V.; Goswami, R.; Jayaraman, T.V. Structure and magnetic properties of milled maraging steel powders. Powder Technol. 2020, 360, 80-95. [CrossRef]

9. Bai, Y.; Wang, D.; Yang, Y.; Wang, H. Effect of heat treatment on the microstructure and mechanical properties of maraging steel by selective laser melting. Mater. Sci. Eng. 2019, 760, 105-117. [CrossRef]

10. Jagadish, C.A.; Priyanka, N. Effect of Cryogenic Treatment on the Mechanical Properties of 18 Ni-300 Grade Maraging Steel Built Using the Direct Metal Laser Sintering (DMLS) Technology. Key Eng. Mater. 2017, 719, 114-121. [CrossRef]

11. Strakosova, A.; Vojtěch, D.; Dvorský, D. Heat Treatment of High-Strength 3D-Printed Maraging Steel. Defect Diffus. Forum 2020, 403, 67-73. [CrossRef]

12. Casati, R.; Lemke, J.; Tuissi, A.; Vedani, M. Aging behaviour and mechanical performance of 18-Ni 300 steel processed by selective laser melting. Metals 2016, 6, 218. [CrossRef]

13. Antsiferov, V.N.; Kolbenev, Y.M. A maraging steel produced by powder metallurgy method. Poroshkovaya Metall. 1972, 4, 40-43. [CrossRef]

14. Menapace, C.; Lonardelli, I.; Molinari, A. Phase transformation in a nanostructured M300 maraging steel obtained by SPS of mechanically alloyed powders. J. Therm. Anal. Calorim. 2010, 101, 815-821. [CrossRef]

15. Hu, Z.Y.; Zhang, Z.-H.; Cheng, X.W.; Wang, F.C.; Zhang, Y.F.; Li, S.L. A review of multi-physical fields induced phenomena and effects in spark plasma sintering: Fundamentals and applications. Mater. Des. 2020, 191, 108662. [CrossRef]

16. Degroat, G. One-Shot Powder Metal Parts. Am. Mach. 1965, 109, 107-109.

17. Tokita, M. Multi-Head Pulse Energization Sintering System. JP Patent No. 2001262202, 9 February 2005.

18. Tokita, M. Method and System for Automatic Electrical Sintering. U.S. Patent No. 6383446, 7 May 2002.

19. Tokita, M.; Nakagawa, K. Rotary Table Type Electric Heating/Pressure Sintering Apparatus. JP Patent No. 2002206102, 11 May 2005.

20. Tokita, M.; Nakagawa, K.; Ishida, S. Shuttle Type Discharge Plasma Sintering System. JP Patent No. 2004244662, 13 September 2006.

21. Adesina, O.; Sadiku, E.; Jamiru, T.; Ogunbiyi, O.; Beneke, L.; Adegbola, A. Optimization of SPS processing parameters on the density and hardness properties of graphene reinforced polylactic acid nanocomposite. Int. J. Adv. Manuf. Technol. 2019, 102, 4047-4058. [CrossRef]

22. Okuni, T.; Miyamoto, Y.; Abe, H.; Naito, M. Joining of AlN and graphite disks using interlayer tapes by spark plasma sintering. Mater. Des. 2014, 54, 755-759. [CrossRef]

23. Tan, Z.; Wang, L.; Xue, Y.; Zhang, P.; Cao, T.; Cheng, X. High-entropy alloy particle reinforced Al-based amorphous alloy composite with ultrahigh strength prepared by spark plasma sintering. Mater. Des. 2016, 109, 219-226. [CrossRef] 
24. Průša, F.; Šesták, J.; Školáková, A.; Novák, P.; Haušild, P.; Karlík, M.; Minárik, P.; Kopeček, J.; Laufek, F. Application of SPS consolidation and its influence on the properties of the FeAl20Si20 alloys prepared by mechanical alloying. Mater. Sci. Eng. A 2019, 761, 138020. [CrossRef]

25. Park, K.; Kim, D.; Kim, K.; Kwon, H. Aluminum/Stainless Steel Clad Materials Fabricated via Spark Plasma Sintering. Materials 2020, 13, 239. [CrossRef] [PubMed]

26. Yang, J.; Guo, Z.; Yang, W.; Luo, J.; Chen, C. Microstructure and Mechanical Properties of 9Cr-ODS Ferritic/martensitic Steels by Mechanically Alloyed and Spark Plasma Sintering. Mater. Sci. Forum 2013, 747-748, 636-640. [CrossRef]

27. Knaislová, A.; Novák, P.; Průša, F.; Cygan, S.; Jaworska, L. Preparation of TiAl15Si15 alloy by high pressure spark plasma sintering. Acta Metall. Slovaca 2018, 24, 174-180. [CrossRef]

28. Molnárová, O.; Málek, P.; Veselý, J.; Minárik, P.; Lukáč, F.; Chráska, T.; Novák, P.; Průša, F. The influence of milling and spark plasma sintering on the microstructure and properties of the Al7075 alloy. Materials 2018, 11, 547. [CrossRef] [PubMed]

29. Pellizzari, M.; Cipolloni, G. Spark Plasma Sintering of Copper Matrix Composites Reinforced with TiB 2 Particles. Materials 2020, 13, 2602. [CrossRef]

30. Olevsky, E.A.; Froyen, L. Constitutive modeling of spark-plasma sintering of conductive materials. Scr. Mater. 2006, 55, 1175-1178. [CrossRef]

31. Sercombe, T.B. The effect of resin type on the sintering of freeformed maraging steel. Mater. Sci. Eng. A 2003, 344, 312-317. [CrossRef]

32. Sercombe, T.B. Sintering of freeformed maraging steel with boron additions. Mater. Sci. Eng. A 2003, 363, 242-252. [CrossRef]

33. Thorpe, A.P.; Sercombe, T.B.; Schaffer, G.B. Sintering of maraging steel with phosphorous additions. Powder Metall. 2005, 48, 47-50. [CrossRef]

34. Tan, C.; Zhou, K.; Ma, W.; Zhang, P.; Liu, M.; Kuang, T. Microstructural evolution, nanoprecipitation behavior and mechanical properties of selective laser melted high-performance grade 300 maraging steel. Mater. Des. 2017, 134, 23-34. [CrossRef]

35. Tariq, F.; Naz, N.; Baloch, R.A. Effect of cyclic aging on mechanical properties and microstructure of maraging steel 250. J. Mater. Eng. Perform. 2010, 19, 1005-1014. [CrossRef] 